\title{
PRESENT-DAY STRESS ORIENTATION AND TECTONIC PULSES REGISTERED IN THE CAVES OF THE SLOVENSKÝ KRAS MTS. (SOUTH-EASTERN SLOVAKIA)
}

\author{
Miloš BRIESTENSKÝ ${ }^{1 * *}$, Zdenko HOCHMUTH ${ }^{2)}$, Juraj LITTVA ${ }^{3,4)}$, Jozef HÓK ${ }^{4)}$, \\ Roman DOBROVIČ $^{2)}$, Josef STEMBERK ${ }^{1)}$, L'ubomír PETRO ${ }^{5)}$ and Pavel BELLA ${ }^{3)}$ \\ ${ }^{1)}$ Department of Engineering Geology, Institute of Rock Structure \& Mechanics, Czech Academy of Sciences, v.v.i., \\ V Holešovičkách 94/41, Prague, 182 09, Czech Republic \\ 2) Institute of Geography, Faculty of Science UPJŠ in Košice, Jesenná 5, 04001 Košice, Slovakia \\ 3) State Nature Conservancy of the Slovak Republic, Slovak Caves Administration, Hodžova 11,031 01 Liptovský Mikuláš, Slovakia \\ 4) Department of Geology and Palaeontology, Faculty of Natural Sciences, Comenius University in Bratislava, \\ Mlynská dolina, Ilkovičova 6, 842 15, Bratislava, Slovakia \\ ${ }^{5)}$ State Geological Institute of Dionýz Štúr, Jesenského 8, 04001 Košice, Slovakia
}

*Corresponding author's e-mail: briestensky@irsm.cas.cz

\begin{tabular}{|c|c|}
\hline ARTICLE INFO & ABSTRACT \\
\hline Article history: & \multirow{9}{*}{$\begin{array}{l}\text { The fault displacement monitoring network EU-TecNet was established to define } \\
\text { microdisplacements across faults in the territory of Central Europe (www.tecnet.cz) using three- } \\
\text { dimensional optical-mechanical extensometers. The results of long-term neotectonic activity } \\
\text { obtained from two caves localized in the eastern part of the Slovenský kras Mts. (SE Slovakia) } \\
\text { show generally NE-SW oriented dilatation. This orientation is in a good accordance with the } \\
\text { orogen-parallel extension monitored in the Western Carpathians. Differing short-lasting trends } \\
\text { were distinguished in } 2011-2012 \text { and } 2013-2015 \text {, which supports the significance of the tectonic } \\
\text { pulse at the end of } 2012 \text { and the beginning of } 2013 \text {. Moreover, simultaneous short-lasting } \\
\text { faulting occurred at both sites under the transtensional tectonic regime, where the principal } \\
\text { maximum compressional axis operated in a NW-SE direction }\left(\sigma_{1}\right) \text {. The observed results were } \\
\text { compared to data from monitoring points in distant areas of the European plate. }\end{array}$} \\
\hline Received 5 January 2018 & \\
\hline Accepted 19 March 2018 & \\
\hline Available online 9 April 2018 & \\
\hline Keywords: & \\
\hline Neotectonics & \\
\hline Microdisplacement monitoring & \\
\hline Cavitonics & \\
\hline Recent geodynamics & \\
\hline
\end{tabular}

\section{INTRODUCTION}

The fault displacement monitoring network EU-TecNet was established to define displacements across faults with a higher accuracy than displacements obtained by the Global Navigation Satellite Systems (GNSS). To-date, the network has collected data from more than one hundred tectonic structures in Central Europe (www.tecnet.cz). Due to the fact that most of the sites are not situated within high seismic-prone regions, it represents the most appropriate data for analysis of fault microdisplacements (Stemberk et al., 2010), reflecting long-term displacement trends due to widespread redistribution of stress and strain within the shallow crust (Košt'ák et al., 2007, 2011; Stemberk et al., 2010; Briestenský et al., 2014a,b). Data on stress-field characteristics are absent in many of the regions and the observatories help to collect such data. The network is equipped with specially designed three-dimensional opticalmechanical extensometers (Košt'ák, 1969), usually installed in underground locations, enabling us to exclude seasonal massif dilatation (Briestenský et al., 2015).

The paper presents the first data concerning the orientation and character of the present-day stress field in the region of south-eastern Slovakia. It also highlights the tectonic pulses recorded using three- dimensional optical-mechanical extensometers, which are different from the long-term observations.

\section{GEOLOGICAL SETTING}

The selected study area is situated on the SE periphery of the Western Carpathians (Fig. 1) and belongs to the most tectonically complicated regions in the Western Carpathians. This is mainly due to the presence of a Jurassic-Cretaceous GemericumMeliaticum and Silicicum nappe stack and later effects of Cenozoic rifting of the Pannonian Basin (Hók et al., 2014; Plašienka, 1997).

Tectonic units of the Gemericum crystalline basement (Palaeozoic), the Meliaticum accretionary complex (Mesozoic), and the cover nappes of the Turnaicum and Silicicum are present in this region (Mello et al., 1996; Geological map of Slovakia, 2013). The Darnó Line or Darnó Zone (Petrik et al., 2016) is an important NNE-SSW trending structural element located in north-eastern Hungary, which reaches the southernmost part of Slovakia on the eastern periphery of the investigated area. The recent mechanism of the Darnó fault zone is assumed to be a sinistral strike-slip (Fodor et al., 2005). From the north, the study area is bordered by the Rožňava Fault (Mello et al., 1996), which cuts the Slovenský kras Mts. into two blocks (Fig. 1) with subsidence of the 

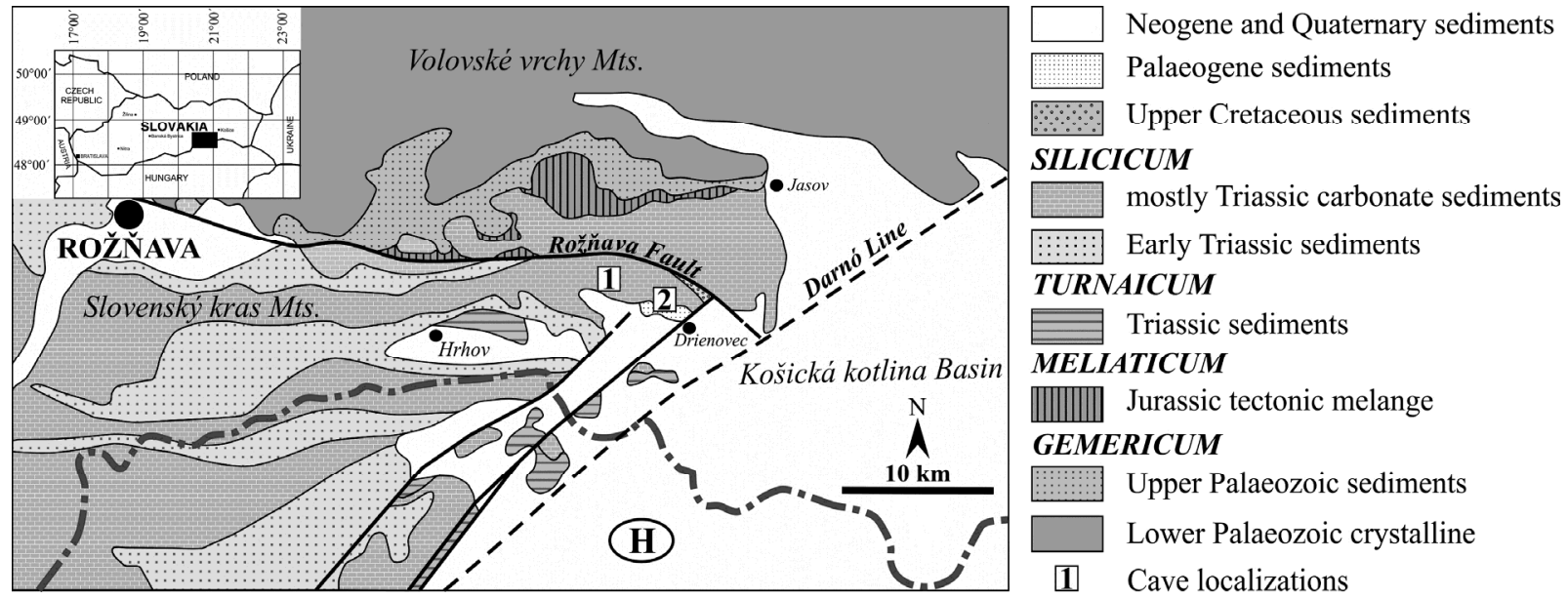

Fig. 1 Simplified geological map with position of the caves: 1) Skalistý potok Cave; 2) Drienovská jaskyňa Cave. Adopted from Fodor et al. (2005) and the Geological map of Slovakia (2013).

southern block (Zacharov, 2009; Maglay et al., 1999). The Rožňava Fault as well as the Darnó Zone show similar orientations to the main extension oriented in a NNE-SSW to NE-SW direction during the Late Miocene (Mello et al., 1996; Petrik et al., 2016). Orientation of the stress field extension component (Littva et al., 2015) yielded a NE-SW striking extension most probably during the Pliocene-Early Pleistocene, and a younger (Late PleistoceneHolocene) WNW-ESE striking extension. Two caves were selected in the eastern part of the Slovenský kras Mts., close to a significant geomorphological contact with the Košická kotlina Basin (Fig. 1; Vass et al., 1994).

\subsection{SKALISTÝ POTOK CAVE}

The Skalistý potok Cave was formed in the Middle Triassic Wetterstein Limestones of the Silicicum (Mello et al., 1996), and represents one of the largest caves in Slovakia. The cave corridors are $7,107 \mathrm{~m}$ in length and have a vertical span of $336 \mathrm{~m}$ (Hochmuth, 2013). Between 1986 and 2000, cave divers led by Hochnuth and Hutňan discovered large spaces, numerous sets of siphons and lakes, as well as an ascending branch with rapids and waterfalls.

Morphologically, the cave consists of two different sections - a lower looping part and an upper ascending part with vertical steps and a subhorizontal corridor (pre-Quaternary paleolevel?). The lower entrance is a short artificial tunnel, built at the site of a karst spring, and the upper entrance is a longer artificial tunnel, which was opened by cavers in 2007. Two extensometric observatories were installed here. The first extensometer was located in the Skalistý potok Cave in October 2011 across the almost N-Sstriking fault $\left(080^{\circ} / 65^{\circ}\right.$, dip direction/dip) close to the upper entrance ( $\left.48^{\circ} 37^{\prime} 45.35^{\prime \prime} \mathrm{N} ; 20^{\circ} 52^{\prime} 15.62^{\prime \prime} \mathrm{E}\right)$. The fault has an affinity to the Darnó Fault Zone and it is supposed to reflect its recent regime. The second gauge was installed in the lowermost entrance (Karst spring 48 $37^{\prime} 23.6^{\prime \prime} \mathrm{N} ; 2^{\circ} 52^{\prime} 16.1^{\prime \prime}$ E) in May 2014 across the NW-SE striking fault $\left(053^{\circ} / 85^{\circ}\right)$, which creates a border between the Slovenský kras Mts. and the Košická kotlina Basin. It is assumed to reflect the subsidence of the basin.

\subsection{DRIENOVSKÁ JASKYŇA CAVE}

The cave $\left(48^{\circ} 37^{\prime} 27.38^{\prime \prime} \mathrm{N} ; 20^{\circ} 57^{\prime} 8.9^{\prime \prime} \mathrm{E}\right)$ is formed in the Upper Triassic (Carnian) grey and dark grey Tisovec limestones of the Silicicum, partly also in carbonatic conglomerate and breccias (the Drienovec conglomerate - Upper Oligocene). The main part of the cave is a fluvial modelled outflow corridor with lakes and cascades. The cave was developed in four levels; its total length reaches $1,348 \mathrm{~m}$ and has vertical span of $85 \mathrm{~m}$ (Zacharov, 2013). It was discovered in the $19^{\text {th }}$ century. In October 2011, one extensometer was installed across the almost W-E striking fault $\left(190^{\circ} / 80^{\circ}\right)$ in the Rožňava Fault Zone.

\section{METHODOLOGY}

The TM-71 optical-mechanical extensometer (hereinafter TM71) was developed for monitoring very slow (some $\mu \mathrm{m}$ per year) three-dimensional displacements across active fault structures, which separate two rock blocks. Its most important advantage is its ability to record three-dimensional data (Fig. 2). The data reflect different types of fault microdisplacements: long-term trends or pressure pulses (in the sense of Stemberk et al., 2010), reflected in initialisation, oscillatory or reversal of the displacements (Fig. 2).

The principles and application of this instrument have already been described by e.g. Košták (1991) and its accuracy has been tested by Marti et al. (2013) and Rowberry et al. (2016). Extensometers record data on the basis of optical-mechanical interferometry, i.e. by generation of moiré patterns (visible between two glass sheets), which are generated by the interference of light rays passing through two specially designed optical grids. Subsequently, the moiré patterns are mathematically transformed into three-dimensional displacement vectors as well as into angular rotations. Extensometers record displacements with an accuracy greater than $5 \mu \mathrm{m}$ and rotations with an accuracy greater than $8.7^{*} 10^{-5} \mathrm{rad}\left(1.4^{*} 10^{-6}\right.$ gon) (Rowberry et al., 2016). The data are usually collected manually using a digital camera with a frequency of once per month, although more than 46 sites have been 


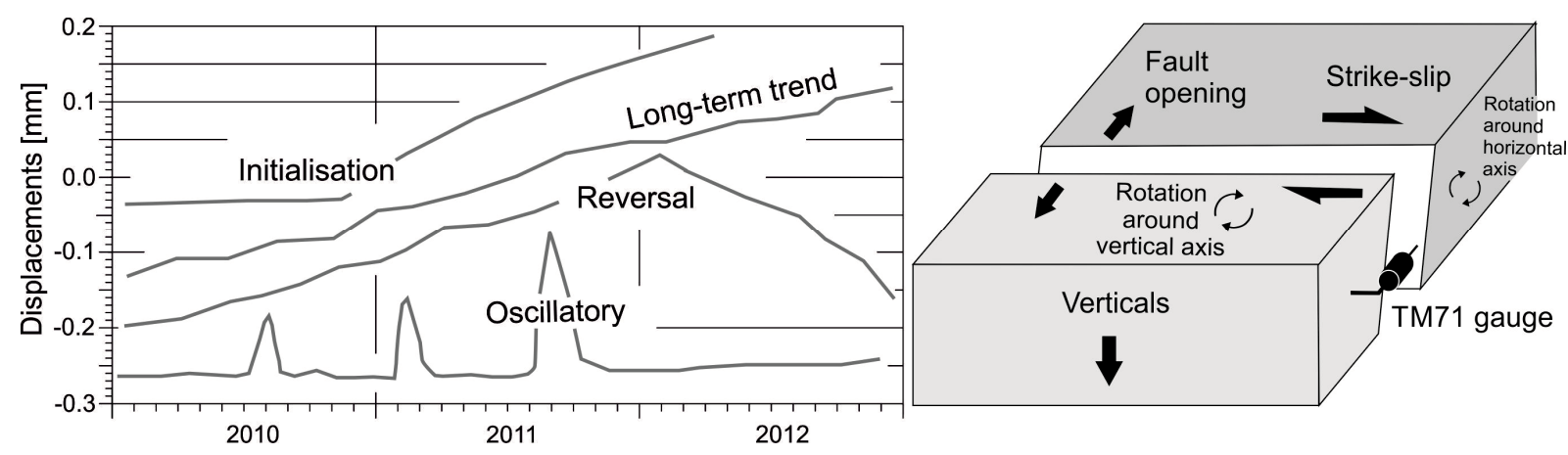

Fig. 2 Character of fault displacements (in the sense of Briestenský et al., 2015) and schematic block model showing all of the fault displacement components registered by the TM71 extensometric instrument.
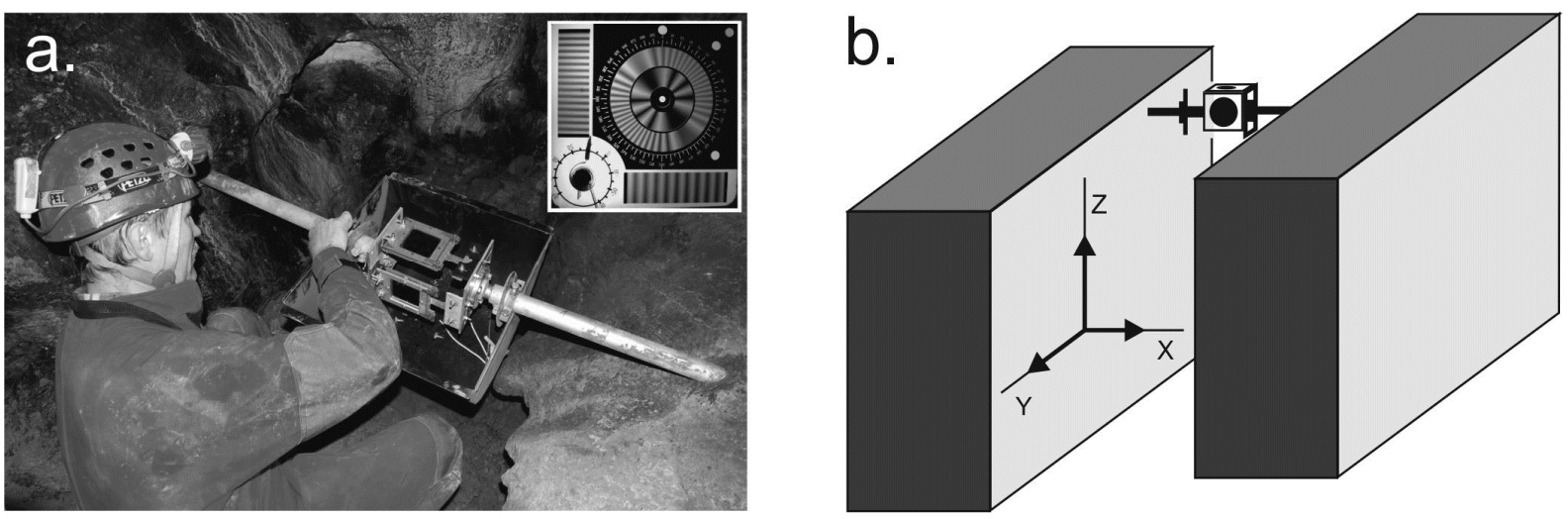

Fig. 3 The picture shows a common installation in the field: a) a TM71 instrument used to measure long-term deformations across a selected fault (photo: P. Staník). The inset shows an example of the moiré fringes registered on one pair of combined indicators; b) the coordinate system used by the TM71 instrument, showing the base vectors $\mathrm{X}, \mathrm{Y}, \mathrm{Z}$. Axis $\mathrm{X}$ represents the crack opening (between two blocks), axis $\mathrm{Y}$ is the strike-slip (horizontal shift), and axis $\mathrm{Z}$ is the vertical component.

equipped with automatic dataloggers with a higher sampling rate since 2009 (Mladečské Caves, Czech Republic). The advantages, disadvantages, and limitations of the instrument have been studied from various points of view as a result of its protracted installation at a number of sites, for example, in the Czech Republic, Slovenia, Slovakia, Austria and Poland (Gosar et al., 2009; Baroň et al., 2016). Moreover, the obtained data have also been compared using other geophysical methods (Košt'ák et al., 2011). They show that seasonal and climatic variations can also be detected and separated from the recorded movement data (Briestenský et al., 2015).

Due to the fact that the monitoring results are presented in Cartesian coordinates (X, Y, Z) (Fig. 3), we used the data to compute a deformation gradient (vector) and its spatial distribution (plunge and azimuth).

The vector can be computed using the following general formula:

$|\mathrm{u}|=\operatorname{root}\left(\mathrm{X}^{\wedge} 2+\mathrm{Y}^{\wedge} 2+\mathrm{Z}^{\wedge} 2\right)$

This vector shows the magnitude of the final displacement across the monitored failure. However, there are many circumstances where its size remains the same, but particular displacement components change. Therefore, individual displacement components still remain as the main indicators in our resulting graphs and papers.

The displacement vector can be defined by the spatial distribution of two angles: azimuth and plunge. Azimuth $(\delta)$ represents the dip direction of the vector. Its value is defined by the relationship between the coordinates $\mathrm{X}, \mathrm{Y}$ (resulting in angle $\alpha$ ) and by the orientation of the gauge in space $(\beta)$ (Fig. 4). There are eight conditions to transform angle $\alpha$ into $360^{\circ}$ horizontal space (Fig. 4). Plunge $(\lambda)$ represents dip, the vertical component of the displacement vector. Its value is defined by the relationship between the coordinate $\mathrm{Z}$ and $\mathrm{Hr}$ (the horizontal resultant of coordinates $\mathrm{X}$ and $\mathrm{Y}$ ).

There are five conditions to transform angle $\lambda$ into $90^{\circ}$ vertical space (Fig. 5). The horizontal resultant $\mathrm{Hr}$ can be computed using the following formula:

$|\mathrm{Hr}|=\operatorname{root}\left(\mathrm{X}^{\wedge} 2+\mathrm{Y}^{\wedge} 2\right)$

Figures 4 and 5 show a schematic model of the azimuth and plunge computations in the case that the $+\mathrm{X}$ coordinate displays an extension, $+\mathrm{Y}$ dextral strike slip and $+Z$ reverse. On the other hand, the real TM71 field situation (method of installation) provides two 


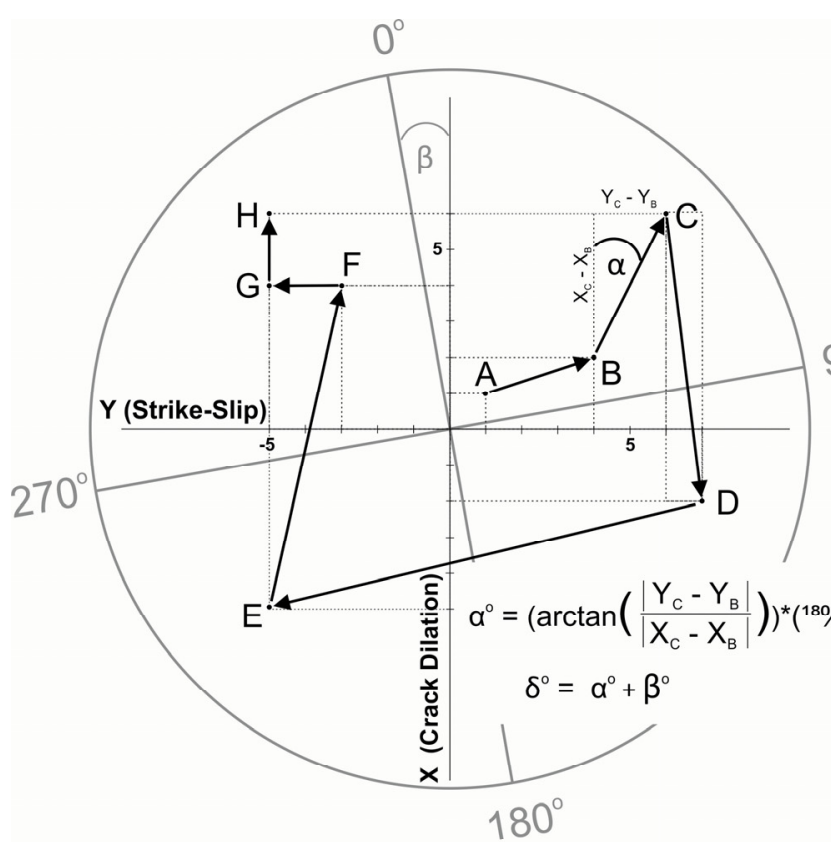

Just for case: $+X=$ extension and $+Y=$ dextral strike-slip

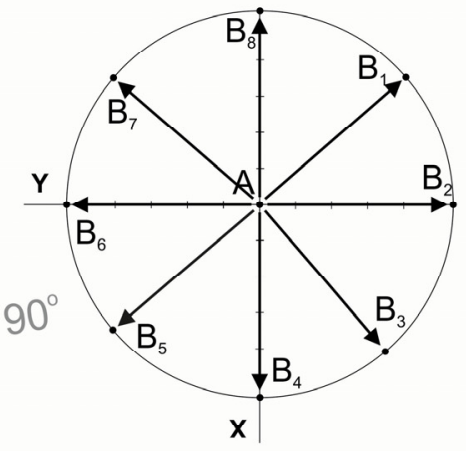

$A B$ : If $\left(X_{B}>X_{A}\right) \wedge\left(Y_{B}>Y_{A}\right) \rightarrow \alpha+0^{\circ}$

$A B_{2}$ : If $\left(X_{B}=X_{A}\right) \wedge\left(Y_{B}>Y_{A}\right) \rightarrow \alpha=90^{\circ}$

$A B_{3}:$ If $\left(X_{B}<X_{A}\right) \wedge\left(Y_{B}>Y_{A}\right) \rightarrow 180^{\circ}-\alpha$

$A B_{\text {. }}$ : If $\left(X_{B}<X_{A}\right) \wedge\left(Y_{B}=Y_{A}\right) \rightarrow \alpha=180^{\circ}$

$A B_{s}:$ If $\left(X_{B}<X_{A}\right) \wedge\left(Y_{B}<Y_{A}\right) \rightarrow \alpha+180^{c}$

$A B_{\text {。 }}$ : If $\left(X_{B}=X_{A}\right) \wedge\left(Y_{B}<Y_{A}\right) \rightarrow \alpha=270^{\circ}$

$A B_{7}$ : If $\left(X_{B}>X_{A}\right) \wedge\left(Y_{B}<Y_{A}\right) \rightarrow 360^{\circ}-\alpha$

$A B_{s}$ : If $\left(X_{B}>X_{A}\right) \wedge\left(Y_{B}=Y_{A}\right) \rightarrow \alpha=360^{\circ}$

Fig. 4 Geometrical parameters used to compute the azimuth $(\delta)$, using the Cartesian coordinates $\mathrm{X}$ and $\mathrm{Y}$ (opening and strike-slip components). The alphabetical numbering shows the order of the observed horizontal fault displacements. Eight conditions represent the eight sectors defined by the $\mathrm{X}$ and $\mathrm{Y}$ relationship. Angle $\beta$ represents the orientation of the TM71 instrument at the selected site.

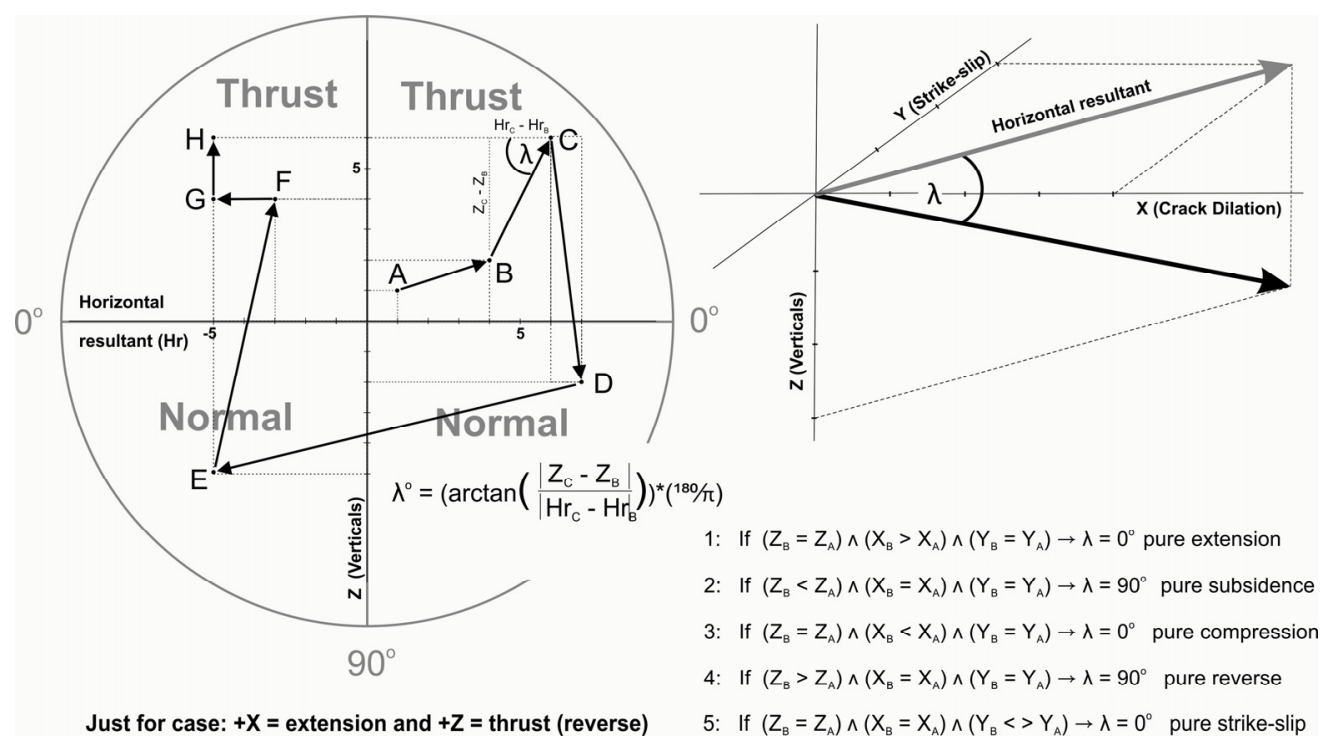

Fig. 5 Geometrical parameters used to compute the plunge $(\lambda)$, using the Cartesian coordinates $X$, $\mathrm{Y}$ and $\mathrm{Z}$ (opening, strike-slip and vertical components). The alphabetical numbering shows the order of the observed vertical fault displacements. Five conditions represent the five thresholds in which the formula does not operate and the results should be substituted by the defined values.

versions of the calculation. These calculations were easy performed using MS Excel, whereby the sense of the microdisplacements is defined verbally. The data were subsequently plotted on a stereographic projection using the Stereo32 software (Röller and Trepmann, 2003). The fault plane was plotted as a large circle, whilst the discrete movement vectors were plotted as points (see Figs. 6, 7 and 8).
Three basic modes of the vector displacement relative to the fault plane could be interpreted: normal or reverse displacement along the dip-slip, dextral or sinistral movement along the strike-slip, and movements related to the opening or closing of the fault fissure. Although the movement vectors usually contained a combination of these movements, the predominant sense of the movement on the vector 


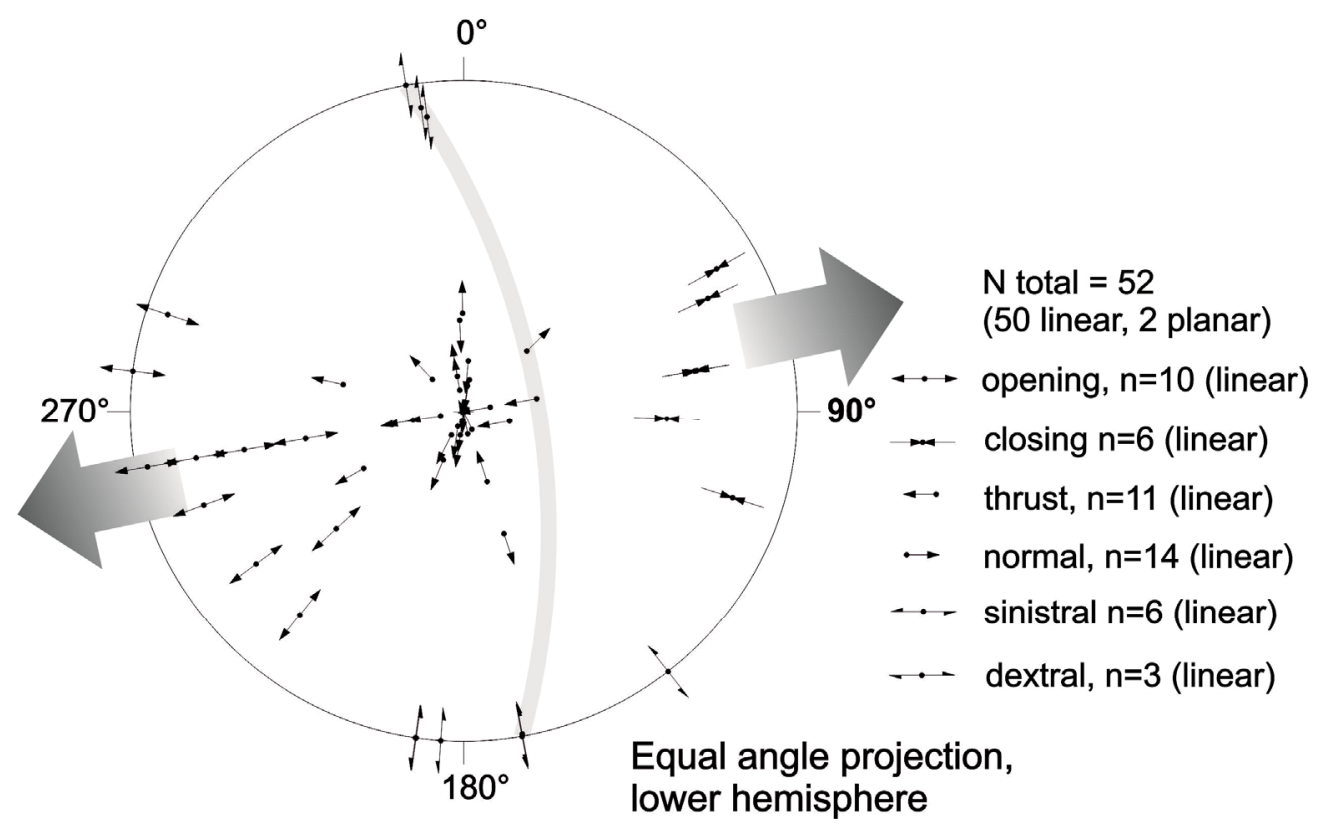

Fig. 6 Long term extension / transtension orientation (grey arrows) recorded in the Skalistý potok Cave.

could be inferred, and the corresponding linear features were marked accordingly. In general, vectors deviating more than $45^{\circ}$ from the strike of the fault were classified as opening/closing, while vectors deviating less than $45^{\circ}$ were classified as dextral/sinistral. However, due to the partial presence of the opening/closing component, which in its pure form is perpendicular to the fault plane (Fig. 2), some of the resulting linear features would be plotted outside of the projected fault plane.

\section{OBTAINED RESULTS}

\subsection{SKALISTÝ POTOK CAVE - UPPER ENTRANCE}

The recorded long-term displacements, 39 records in the period from October 2011 to January 2015, can be characterized as subsidence of the eastern block ( $12.5 \mu \mathrm{m} /$ year $)$ in an extensional regime, demonstrated by weak fault opening $(12.5 \mu \mathrm{m} / \mathrm{year}$, Figs. 6 and 7).

Moreover, the displacement components are not affected by the peak-to-peak amplitude caused by seasonal massif dilatation. Three significant events were registered, which changed some of the movement components. A notable tectonic pulse occurred at the end of 2012 and the beginning 2013, which is coincident with the pulse registered at many sites in Europe (Briestenský et al., 2015) and changed the displacement trends. A reversal in rotations is visible at this site as well. Different trends were observed in vertical as well as horizontal rotations before and after the event (rotation around the vertical axis: a counter clockwise 0.02 gon/year trend of the eastern block in the period 2011-2012 and a clockwise 0.012 gon/year trend of the eastern block in the period 2013-2014; a downward fault opening 0.02 gon/year trend of the eastern block in the period 2011-2012 and an upward 0.014 gon/year trend of the eastern block in the period 2013-2015). The second event had a very short duration and was opposite to the long-term trend. The fault closed at the end of 2014 and beginning of 2015 and was followed by a fault opening with a significant sinistral strike-slip (first half of 2015, Fig. 7). In the second half of 2015 there was a dextral strike-slip, probably a relaxation of the strike-slip, along the fault and no rotation around the vertical axis was observed (Fig. 7). The sinistral strike-slip is in good accordance with the sinistral strike-slip mechanism along the Darnó Fault Zone (Fodor et al., 2005).

\subsection{SKALISTÝ POTOK CAVE - KARST SPRING}

Due to the fact that the gauge was installed in 2014, it was not possible to define the long-term displacement trend (Fig. 8). Only the rotation around the horizontal axis shows a 0.04 gon/year downward fault opening tendency. The stereographic projection (Fig. 8) mainly shows alternating normal or reverse dip-slip and dextral and sinistral strike slips.

\subsection{DRIENOVSKÁ JASKYŇA CAVE}

The observed long-term tectonic activity shows a similar orientation to the main extension component of the present-day stress field as it was registered in the Skalistý potok Cave (Fig. 6 and Fig. 9).

The data (Fig. 10) display the same tectonic pulses as in the Skalistý potok Cave - upper entrance. A pulse was observed in 2013 (period B), which was accompanied by a strike-slip oscillation, southern block thrust and downward fault opening (Fig. 10). The second pulse caused initialization of southern block subsidence and counter clockwise rotation around the vertical axis in 2014. We have observed an initialization of the dextral strike-slip together with subsidence since the end of 2014, which shows oblique normal faulting. The stereographs also show the onset of increased dextral strike-slip movements in 


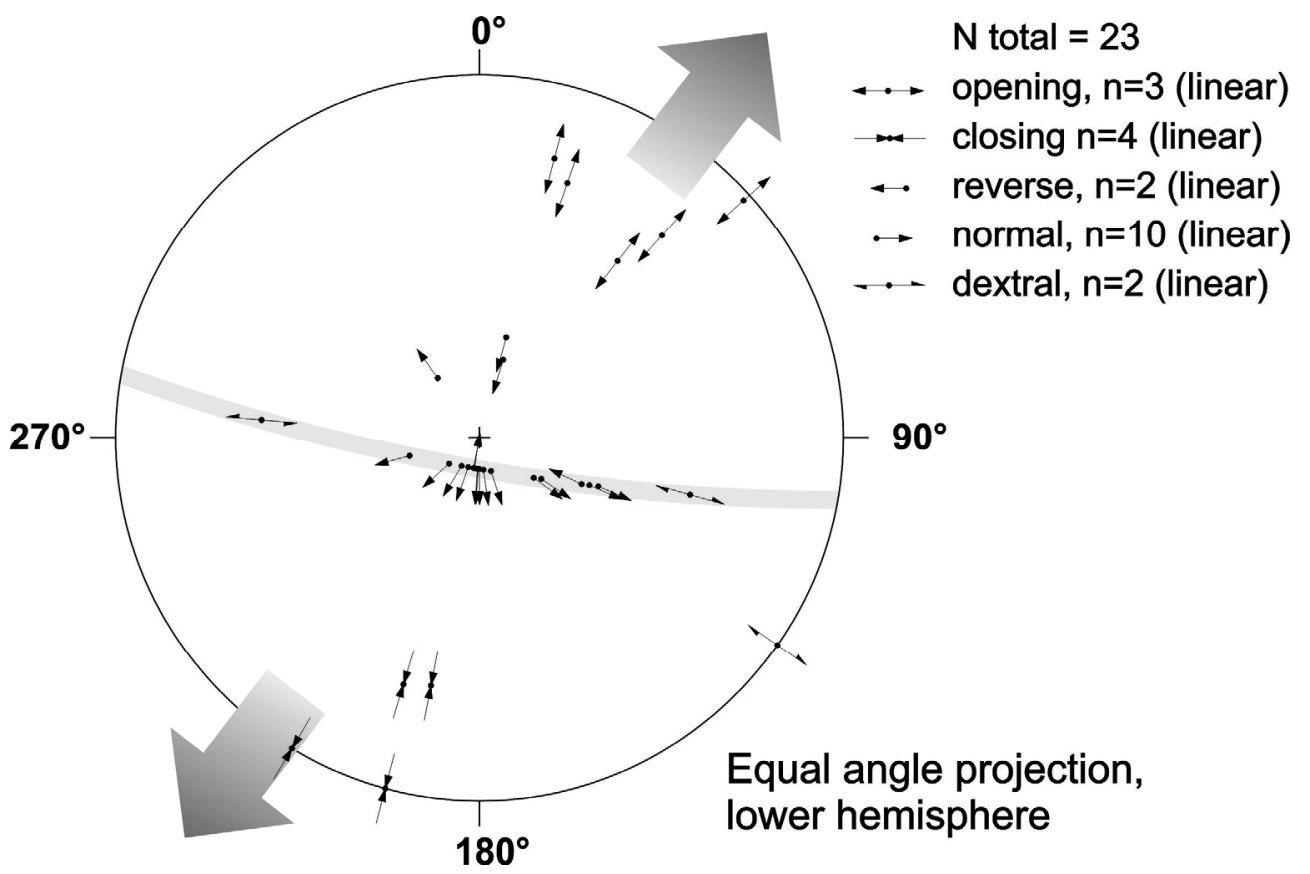

Fig. 9 Long term extension / transtension orientation (grey arrows) recorded in Drienovská jaskyn̆a Cave.

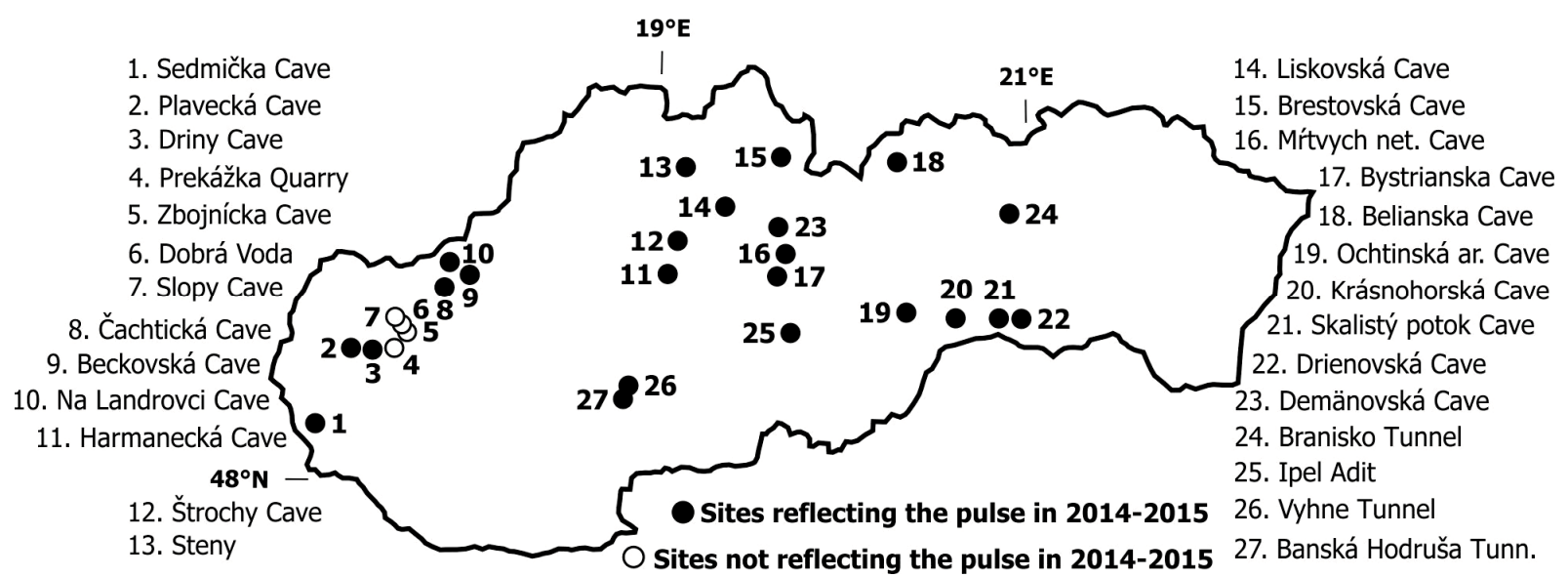

Fig. 12 The monitoring sites (of IRSM and SGIDS) in Slovakia: the black dots represent monitoring points demonstrating the proposed tectonic pressure of the 2014-2015 pulse, while the white dots represent the points that do not offer any evidence of the proposed pulse.

the last period (Fig. 10D). Normal faulting is in good accordance with the mechanism of the Rožňava Fault, separating the northern and southern Slovenský kras Mts. blocks, with southern block subsidence (Zacharov, 2009).

\section{DISCUSSION}

Two events with increased fault displacement or tectonic pulses were observed in the Skalistý potok Cave and Drienovská jaskyňa Cave. These disturbances were observed at many sites throughout Europe with different fault kinematics (Briestenský et al., 2015). The last tectonic pulse in the second half of 2014 was observed in e.g., Spitsbergen 3,172 km to the north and in Greece $1,156 \mathrm{~km}$ to the south (Fig. 11). It was also observed at most of the sites in the Slovak network (Fig. 12).

The pulse was one of the most powerful tectonic pulses registered by EU-TecNet (Stemberk et al.,
2010, 2015; Briestenský et al., 2014 a, 2014 b, 2015). It was primarily registered as a strike-slip component, which proves its tectonic origin. This change closed the 2012/2014 period of sinistral strike-slip displacements in the Driny Cave (western Slovakia, Fig. 13), which reflects local tectonics and changes in faulting trends.

Due to the fact that many of the observatory points are only (manually) monitored once a month, it is not possible to accurately estimate the onset of the 2014 pulse. Generally, it began in July/August 2014. On the other hand, there are some sites that are now equipped with automatic dataloggers, which enables us to specify the exact start and the end of the tectonic pulse. Such a site is the 13C Cave (Moravian Karst, Czech Republic, www.tecnet.cz) with data acquired once a day (Fig. 14).

Generally, the event began here on the $9^{\text {th }}$ of August 2014 and finished on the $1^{\text {st }}$ of February 2015. 


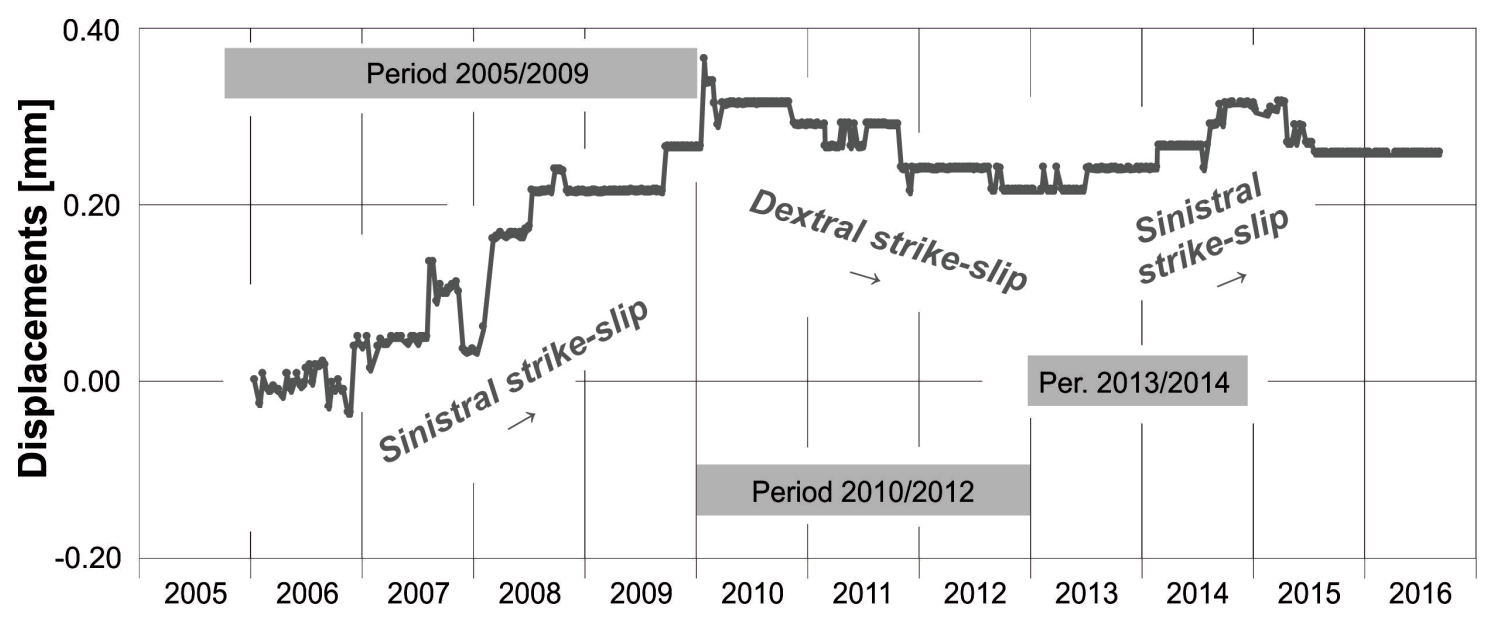

Fig. 13 Strike-slip displacements along the NNE-SSW striking fault in the Driny Cave ( $275 \mathrm{~km}$ westward) in the western part of the Western Carpathian Arc, which show four periods with different strike-slip mechanisms. The mechanisms changed at the end of 2009, 2012 and 2014. The last two reversals (2012/2013 and 2014/2015) correspond to rotation reversal in the Skalistý potok and significant faulting in the Drienovská jaskyňa and Skalitstý potok caves.

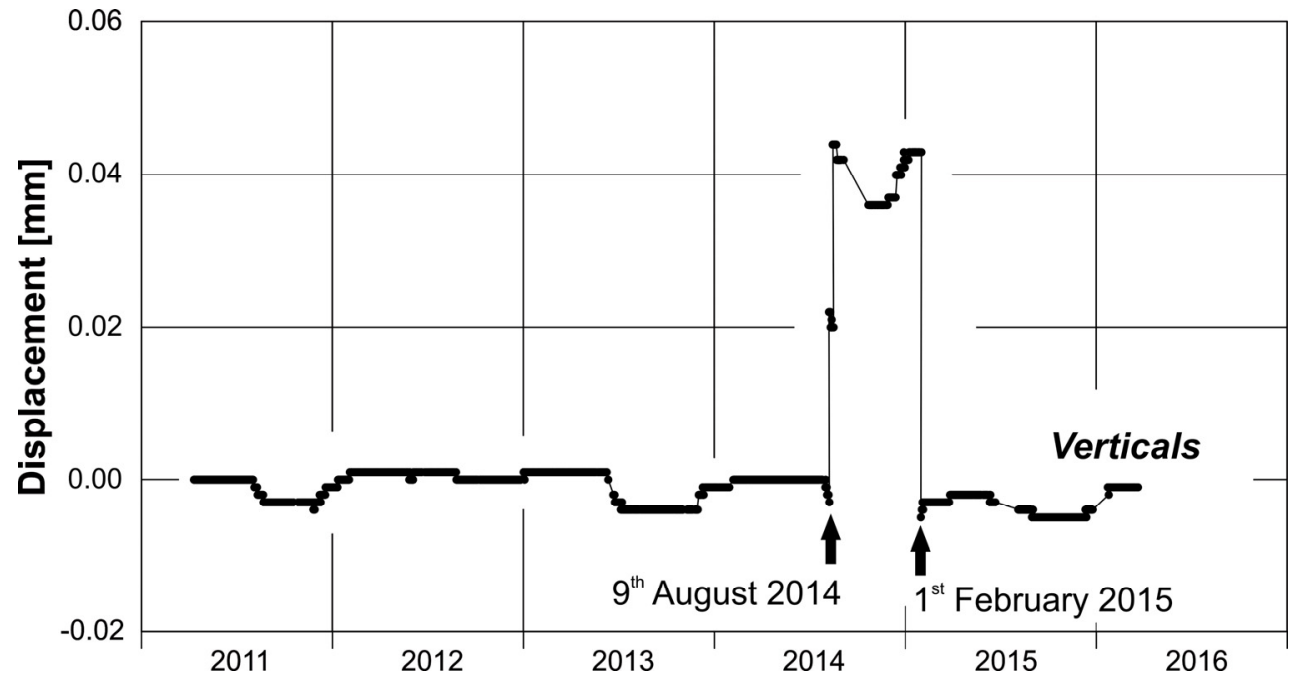

Fig. 14 The vertical displacement component registered along a N-S striking fault in the 13C Cave in the Moravian Karst (Czech Republic, $312 \mathrm{~km}$ west-north-westward from the Skalistý potok Cave). The site represents the second automated gauge with a data acquisition frequency of once a day, which helped to define the start and the end of the tectonic pulse at the end of 2014/beginning of 2015 .

There are many studies that correlate distant postseismic displacements (e.g. Bykov, 2005; Tregoning et al., 2013), but no significant seismic effect was found that could play a role in postseismic deformation affecting the whole of the European plate in the second half of 2014. The event was not preceded by any earthquake with $\mathrm{M}_{\mathrm{W}}>8$ (www.usgs.gov). On the other hand, the pulse occurred in a large seismic global cycle window with a high number of earthquakes with $\mathrm{M}_{\mathrm{W}}>8$, which caused far-field crustal deformation. This cycle started in 2000 (Tregoning et al., 2013).

There are other trigger mechanisms for active faulting like the change in the angular speed of the Earth's rotation (ASER), which is assumed to trigger the majority of earthquakes (Ostřihanský, 2012; Trofimenko and Bykov, 2017). The 13C Cave (Trináctka Cave) data (Fig. 14) indicate that the LOD (length of day), which represents a deceleration and acceleration of ASER, could correlate with the fault slips (Fig. 15).

Moreover, Riguzzi et al. (2010) presented a theory that a significant portion of tidal energy is also converted into tectonic processes. Kalenda et al. (2015) determined that microseims have the same annual distribution as LOD variations (changes in ASER) and they accompany a drift in the westward tectonic plates. Tidal torque decelerates the ASER (Scopolla et al., 2006); hence, it has a seasonal character. Figure 11 shows that changes between significant tectonic periods also finish at the end of the year. Furthermore, microdisplacements in the Drienovská Cave and the 13C Cave followed a shortlasting minimum LOD (maximum of the ASER) with a 2-day delay (in agreement with the 2-day earthquake delay published by Ostřihanský, 2012). Therefore, ongoing fault displacement monitoring should prove or rebut the role of ASER in active tectonics, not be 


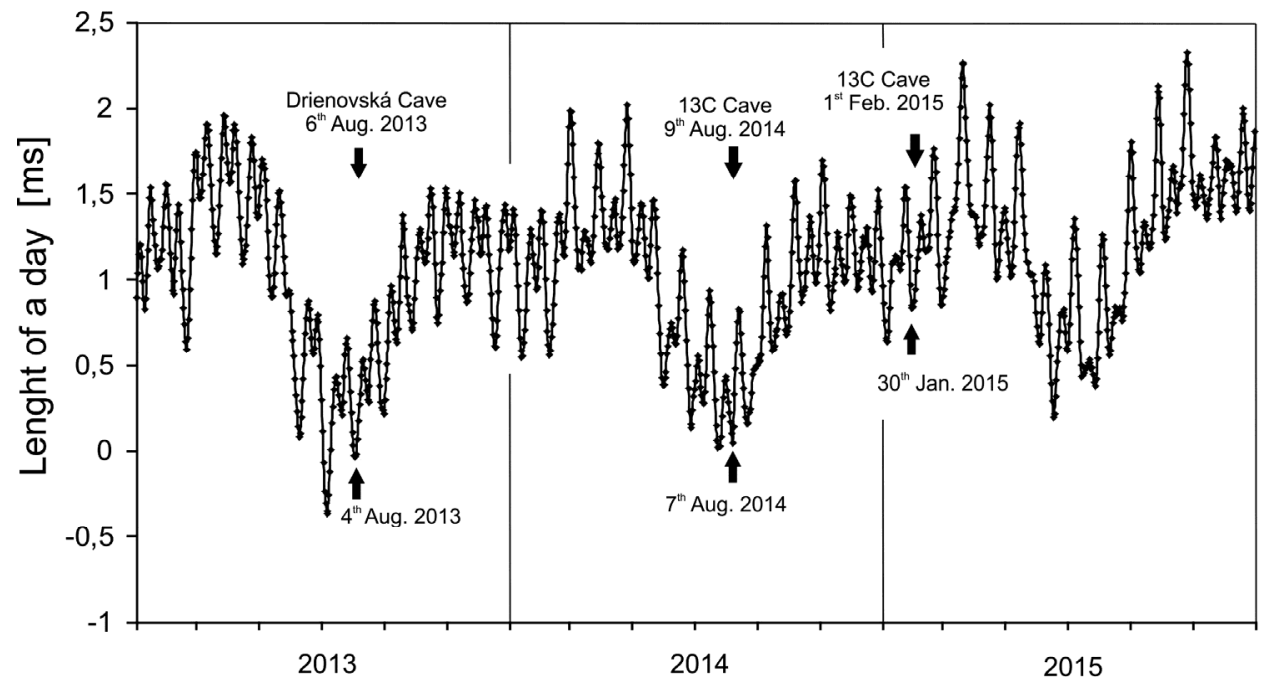

Fig. 15 The coincidence of the LOD (length of day, source: https://www.iers.org) and the discussed displacements with the accurate date in the Drienovská Cave and the 13C Cave in 2013, 2014 and 2015. The displacements followed a short-lasting LOD minimum (maximum of the angular speed of the Earth's rotation) with a 2-day delay (in agreement with the 2-day earthquake delay published by Ostrihanský, 2012). The lower arrows show the short-lasting LOD minimum and the upper arrows represent the beginning of the displacements.

regarded as the origin of the fault displacements, but as a triggering mechanism depending on the stress background.

\section{CONCLUSION}

Long-term tectonic activity determined in the Skalistý potok and Drienovská caves is characterized by an extension of the transtension regime with the $\mathrm{S}_{\mathrm{hmin}}$ orientation in a NE-SW to ENE-SWS direction. Orientation of the $\mathrm{S}_{\mathrm{hmin}}$ is in good agreement with the results of the cavitonics obtained from the western part of the Slovenský kras Mts. (Littva et al., 2015) and also with orogen-parallel extension monitored in the Western Carpathian realm (Hók et al., 2016).

Block rotations in the Skalisty potok and Drienovská jaskyn̆a caves indicate a change in the long-term tectonic regime, which started in 2013 across the various regions of Europe (Briestenský et al., 2015).

The most significant fault microdisplacements occurred in first half of 2015, when the NNW-SSE sinistral strike-slip fault (in the Skalistý potok Cave upper entrance) together with the WNW-ESE dextral strike-slip fault (in the Drienovská jaskyn̆a Cave) were reactivated under the transtensional tectonic regime, where the principal maximum compressional axis operated in a NW-SE direction $\left(\sigma_{1}\right)$ during this shortlasting period.

The observed results were compared to data from monitoring points in other regions of the European plate, regarding e.g., the northern site in Spitsbergen and the south-eastern site in Greece. Many sites showed evidence of a simultaneous microdisplacement anomaly in the second half of 2014/ beginning of 2015, which is interpreted to reflect the occurrence of a tectonic pressure pulse towards the second half of 2014.

\section{ACKNOWLEDGEMENT}

This study was conducted thanks to the support of the long-term conceptual development research organization RVO: 67985891. The EU-TecNet fault displacement monitoring network was established within the framework of the COST Action project entitled "3-D Monitoring of Active Tectonic Structures". This paper is published within the framework of the CzechGeo-EPOS project "Distributed system of permanent observatory measurements and temporary monitoring of geophysical fields in the Czech Republic" (MŠMT Project: LM2015079). The authors also wish to acknowledge the financial support provided by the Czech Ministry of Education, Youth, and Sports (COST OC 625.10 and LM2010008).

\section{REFERENCES}

Baroň, I., Plan L., Grasemann, B., Mitrovic, I., Lendhard, W., Hausmann, H. and Stemberk, J.: 2016, Can deep seated gravitational slope deformations be activated by regional tectonic strain: First insights from displacement measurements in caves from the Eastern Alps. Geomorphology, 259, 81-89.

DOI: 10.1016/j.geomorph.2016.02.007

Briestenský, M., Stemberk, J. and Rowberry, M.D.: 2014a, The use of damaged speleothems and in situ fault displacement monitoring to characterise active tectonic structures: an example from Západní Cave, Czech Republic. Acta Carsologica, 43, 129-138. DOI: 10.3986/ac.v43i1.626

Briestenský, M., Thinová, L., Praksová, R., Stemberk, J., Rowberry, M.D. and Knejflová, Z.: 2014b, Radon, carbon dioxide, and fault displacements in central Europe related to the Tōhoku Earthquake. Radiat. Prot. Dosimetry, 160, 78-82. DOI: $10.1093 / \mathrm{rpd} / \mathrm{ncu} 090$

Briestenský, M., Rowberr, M.D., Stemberk, J., Stefanov, P., Vozár, J., Šebela, S., Petro, L., Bella, P., Gaal, L. and 
Ormukov, Ch.: 2015, Evidence of a plate-wide tectonic pressure pulse provided by extensometric monitoring in the Balkan Mountains (Bulgaria). Geol. Carpath., 66, 427-438.

DOI: $10.1515 /$ geoca-2015-0035

Bykov, V.G.: 2005, Strain waves in the Earth: Theory, field data, and models. Russian Geology, Geophysics, 46, $1158-1170$.

Fodor, L., Radócz, G., Sztanó, O., Koroknai , B., Csontos, L. and Harangi, Sz.: 2005, Post-Conference Excursion: Tectonics, sedimentation and magmatism along the Darnó Zone. Geolines, 19, 142-162.

Geological map of Slovakia (Geologická mapa Slovenska) M 1:50 000 [online], 2013. Bratislava, State Geological Institute of Dionýz Štúr. Available online: http://mapservergeology.sk/gm50js

Gosar, A., Šebela, S., Košták, B. and Stemberk, J.: 2009, Surface versus underground measurements of active tectonic displacements detected with TM71 extensometers in western Slovenia. Acta Carsologica, 38, 213-226. DOI: 10.3986/ac.v38i2-3.123

Hochmuth, Z.: 2013, Atlas of the Skalistý potok Cave. Slovak Speleological Society, Liptovský Mikuláš, 80 pp., (in Slovak).

Hók, J., Kysel, R., Kováč, M., Moczo, P., Kristek, J., Kristeková, M. and Šujan, M.: 2016, A seismic source zone model for the seismic hazard assessment of Slovakia. Geol. Carpath., 67, 3, 273-288. DOI: $10.1515 /$ geoca-2016-0018

Hók, J., Šujan, M. and Šipka, F.: 2014, Tectonic division of the Western Carpathians: an overview and a new approach. Acta Geol. Slovaca, 6, 2, $135-143$, (in Slovak).

Kalenda, P., Wandrol, I., Holub, K. and Rušajová, J.: 2015, The possible explanation for secondary microseisms seasonal and annual variations. Terr. Atmos. Ocean. Sci., 26, 2, 103-109.

DOI: $10.3319 / \mathrm{TAO} .2014 .10 .15 .01(\mathrm{~T})$

Košt’ák, B.: 1969, A new device for in situ movement detection and measurement. Exp. Mech., 9, 8, 374379. DOI: $10.1007 / \mathrm{BF} 02327715$

Košták, B.: 1991, Combined indicator using moiré technique. In: Sorum , G. (Eds.): Field Measurements in Geomechanics: Proceedings of the 3rd International Symposium, 9th-11th September 1991, Oslo. Balkema, Rotterdam, 53-60.

Košták, B., Cacoń, S., Dobrev, N.D., Avramova-Tacheva, E., Fecker, E., Kopecký, J., Petro, L., Schweizer, R. and Nikonov, A.A.: 2007, Observations of tectonic microdisplacements in Europe in relation to the Iran 1997 and Turkey 1999 earthquakes. Izv. Phys. Solid Earth, 43, 6, 503-516. DOI: $10.1134 / \mathrm{S} 1069351307060080$

Košt’ák, B., Mrlina, J., Stemberk, J. and Chán, B.: 2011, Tectonic movements monitored in the Bohemian Massif. J. Geodyn., 52, 1, 34-44. DOI: 10.1016/j.jog.2010.11.007

Littva, J., Hók, J. and Bella, P.: 2015, Cavitonics: Using caves in active tectonic studies (Western Carpathians, case study). J. Struct. Geology, 80, 47-56. DOI: 10.1016/j.jsg.2015.08.011

Maglay, J., Halouzka, R., Baňacký, V., Pristaš, J. and Janočko, J.: 1999, Neotectonic map of Slovakia 1:500 000. Ministry of Environment of Slovak Republic, Bratislava.

Marti, X., Rowberry, M.D. and Blahůt, J.: 2013, A MATLAB $®$ code for counting the moiré interference fringes recorded by the optical-mechanical crack gauge TM-71. Comput. Geosci, 52, 164-167. DOI: 10.1016/j.cageo.2012.09.029

Mello, J., Elečko, M., Pristaš, J., Reichwalder, P., Snopko, L., Vass, D. and Vozárová, A.: 1996, Geological map of the Slovak Karst 1:50 000. MŽP and GSSR, Bratislava, (in Slovak).

Ostřihanský, L.: 2012, Earth's rotation variations and earthquakes 2010-2011. Solid Earth Discuss., 4, 33130. DOI: $10.5194 /$ sed-4-33-2012

Petrik, A., Beke, B., Fodor, L. and Lukács, R.: 2016, Cenozoic structural evolution of the southwestern Bükk Mts. and the southern part of the Darnó deformation belt (NE Hungary). Geol. Carpath., 67, 1, 83-104. DOI: 10.1515/geoca-2016-0005

Plašienka, D.: 1997, Cretaceous tectochronology of the Central Western Carpathians, Slovakia. Geol. Carpath., 48, 2, 99-111.

Riguzzi, F., Panza, G., Varga, P. and Doglioni, C.: 2010, Can Earth's rotation and tidal despinning drive plate tectonics? Tectonophysics, 484, 1-4, 60-73. DOI: $10.1016 /$ j.tecto.2009.06.012

Rowberry, M.D., Kriegner, D., Holý, V., Olejník, K., Llull, M., Frontera, C. and Marti, X.: 2016, The instrumental resolution of a moiré extensometer in light of its recent automatization. Measurement, 91, 258-265. DOI: 10.1016/j.measurement.2016.05.048

Röller, K. and Trepmann, C.A.: 2003, Stereo32, software. Ruhr-Universität Bochum, Germany.

[http://www.ruhr-unibochum.de/hardrock/downloads.html].

Scoppola, B., Boccaletti, D., Bevis, M., Carminati, E. and Doglioni, C.: 2006, The westward drift of the lithosphere: A rotational drag? Geol. Soc. Am. Bull., 118, 1-2, 199-209. DOI: 10.1130/B25734.1

Stemberk, J., Košt’ák, B. and Cacoń, S.: 2010, A tectonic pressure pulse and increased geodynamic activity recorded from the long-term monitoring of faults in Europe. Tectonophysics, 487, 1-12. DOI: $10.1016 /$ j.tecto. 2010.03 .001

Stemberk, J., Briestenský, M. and Cacoń, S.: 2015, The recognition of transient compressional fault slow-slip along the northern shore of Hornsund Fjord, SW Spitsbergen, Svalbard. Pol. Polar Res., 36, 2, 109-123. DOI: 10.1515/popore-2015-0007

Tregoning, P., Burgette, R., McClusky, S.C., Lejeune, S., Watson, C.S. and McQueen, H.: 2013, A decade of horizontal deformation from great earthquakes. J. Geophys. Res., Solid Earth 118, 2371-2381. DOI: $10.1002 /$ jgrb.50154

Trofimenko, S.V. and Bykov, V.G.: 2107: Spatiotemporal distribution of earthquakes in the northeastern segment of Amur plate in two phases of variations in the modulus of the Earth's rotation rate. J. Volcanol. Seismol., 11, 2, 143-155. DOI: $10.1134 /$ S0742046317020087

Vass, P., Elečko, M., Horská, A., Petřík, F., Barkač, Z., Mello, J., Vozárová, A. and Dubéci, B.: 1994, Basic sketch of the Turnianská depresia Basin. Geologické práce, Správy, 99, 7-22, (in Slovak).

Zacharov, M.: 2009, Evaluation of sensitivity of rock and vulnerability of rock environment on the eastern part of the Horný vrch plateau and southern part Zádiel plateau. Acta Montan. Slovaca, 14, 1, 1-11, (in Slovak).

Zacharov, M.: 2013, New findings from the Drienovecká jaskyňa Cave research. Slovenský kras, 51, 2, 111120, (in Slovak). 

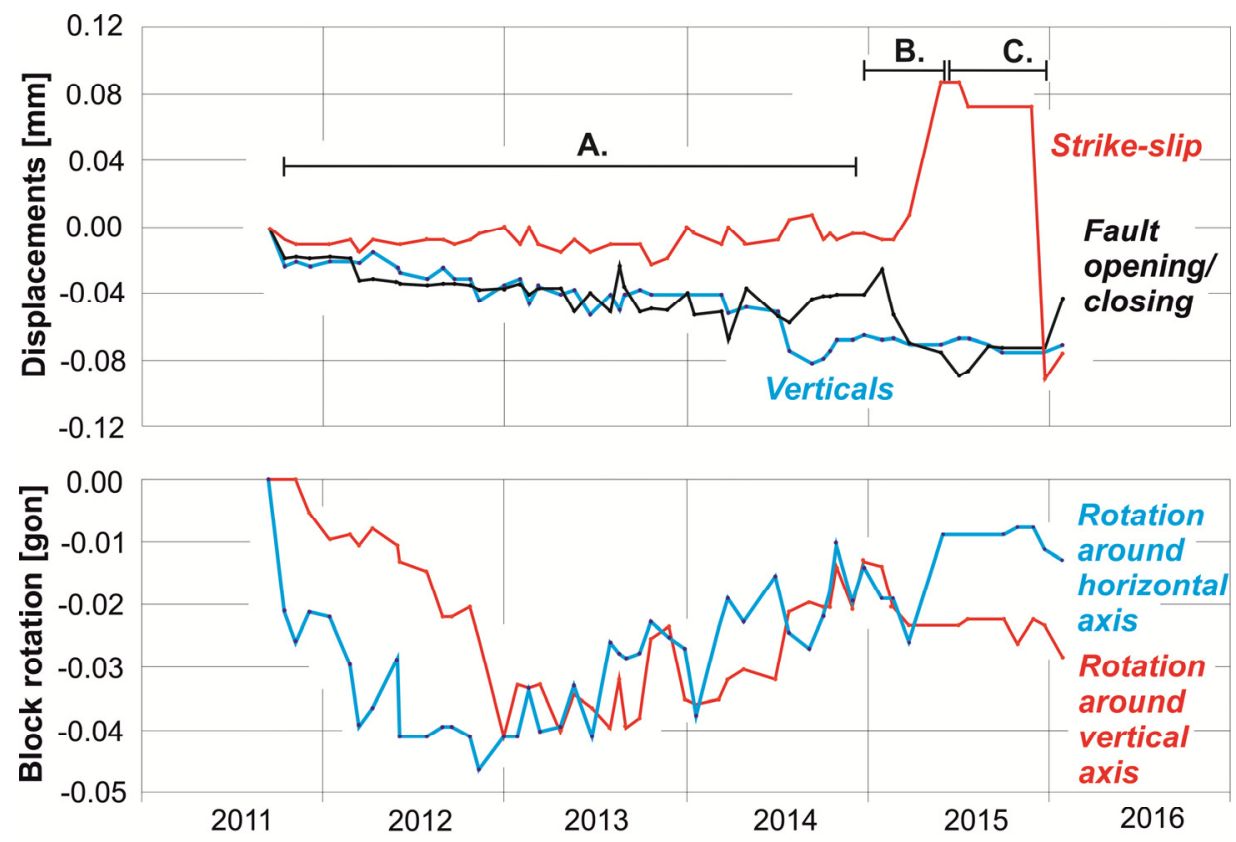

A.

B.
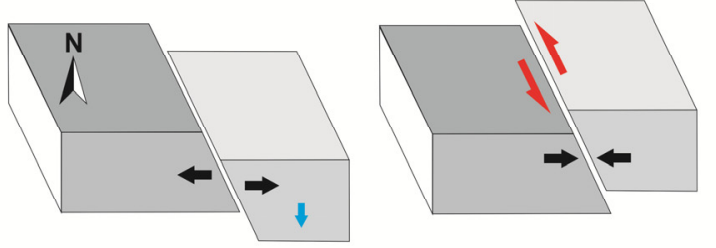

Period 2011-2012

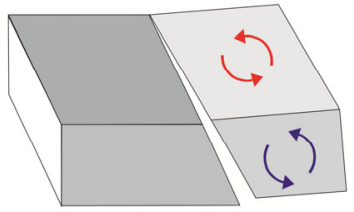

Period 2013-2014

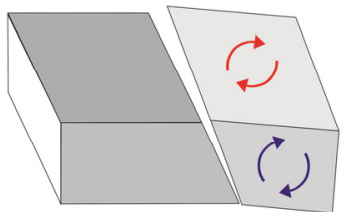

Period 2015-2016

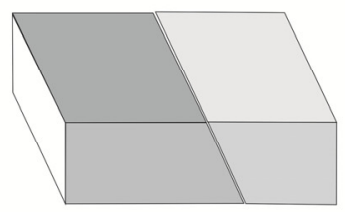

苗

Fig. 7 The fault displacements and block rotations recorded in the Skalistý potok Cave - upper entrance. The block diagrams show a schematic model of the long-term block movements, significant faulting periods (blue arrow - verticals, black arrow - fault opening/closing, red arrow - strikeslip), block rotation and periods of block rotation changes (blue arrow - rotation around horizontal axis, red arrow - rotation around vertical axis).

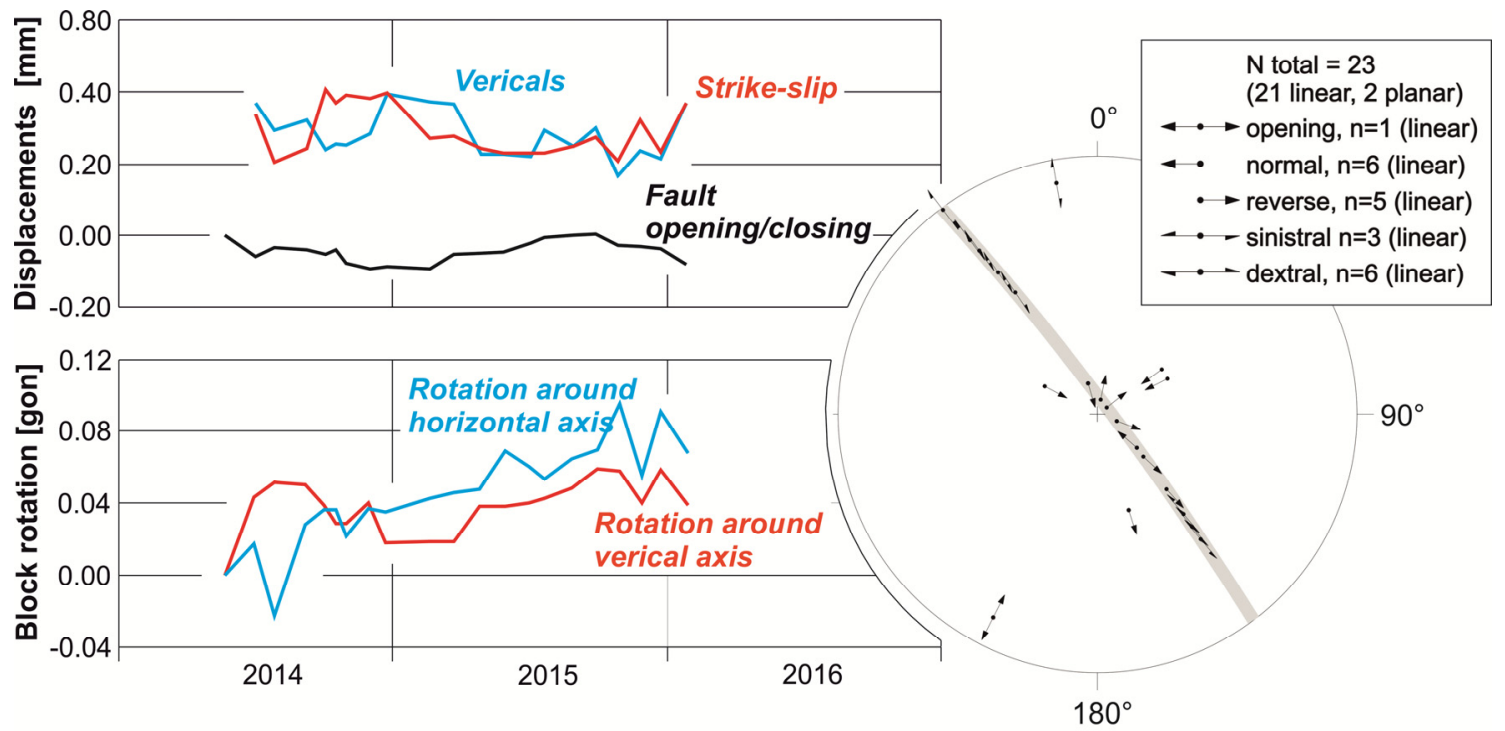

Fig. 8 The fault displacements and block rotations recorded in the Skalistý potok Cave - karst spring. The right image shows the stereographic projection of the plotted fault plane (thick grey great circle) and the displacement vectors projected as tangent lines. 


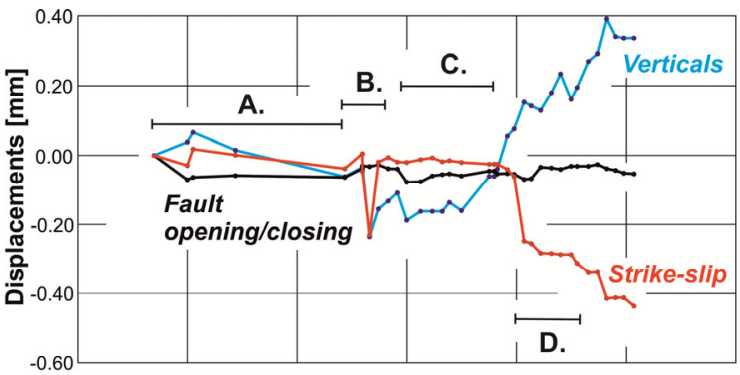

B.
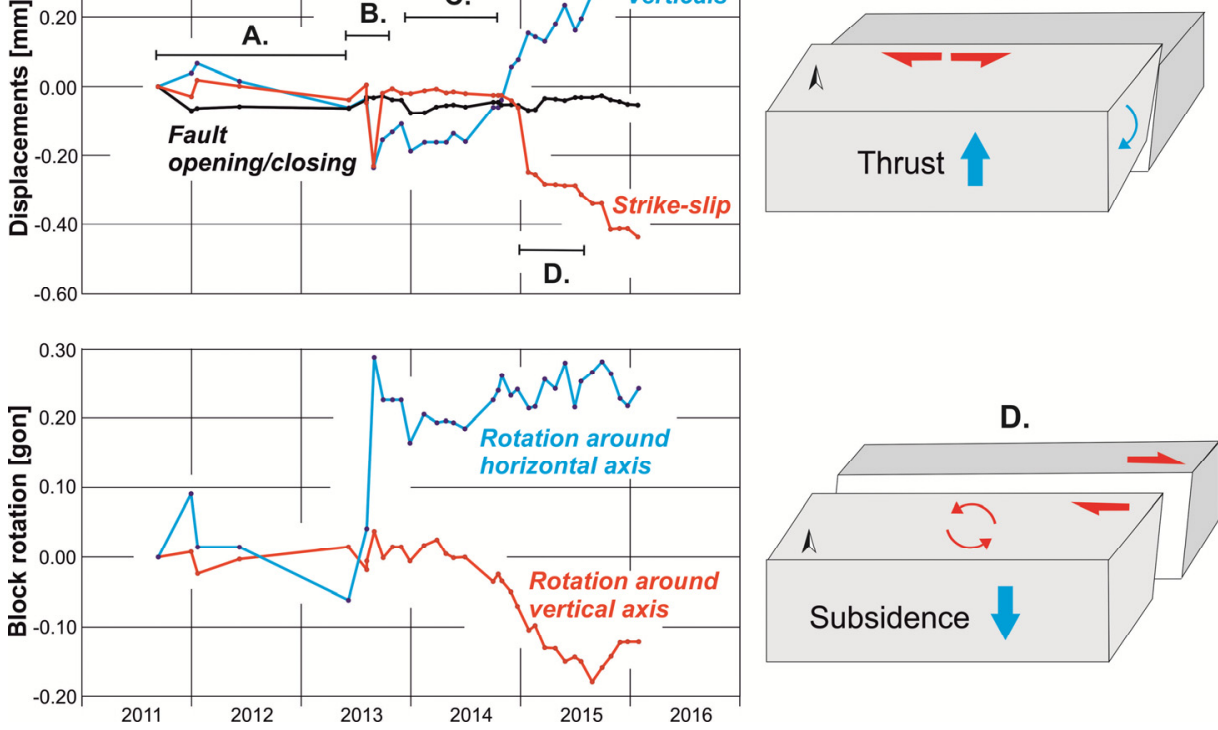

D.

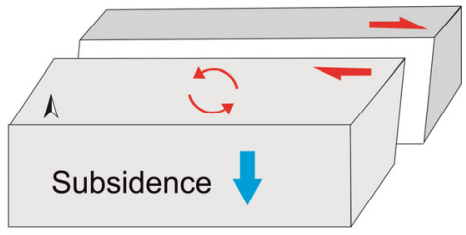

Fig. 10 The fault displacements and block rotations recorded in the Drienovská jaskyňa Cave. The block diagrams show a schematic model of the significant pulse in 2013 (B.) and displacement initializations in 2014/2015 (D.) (blue arrow - subsidence, thrust and rotation around horizontal axis, red arrow - strike-slip and rotation around vertical axis).
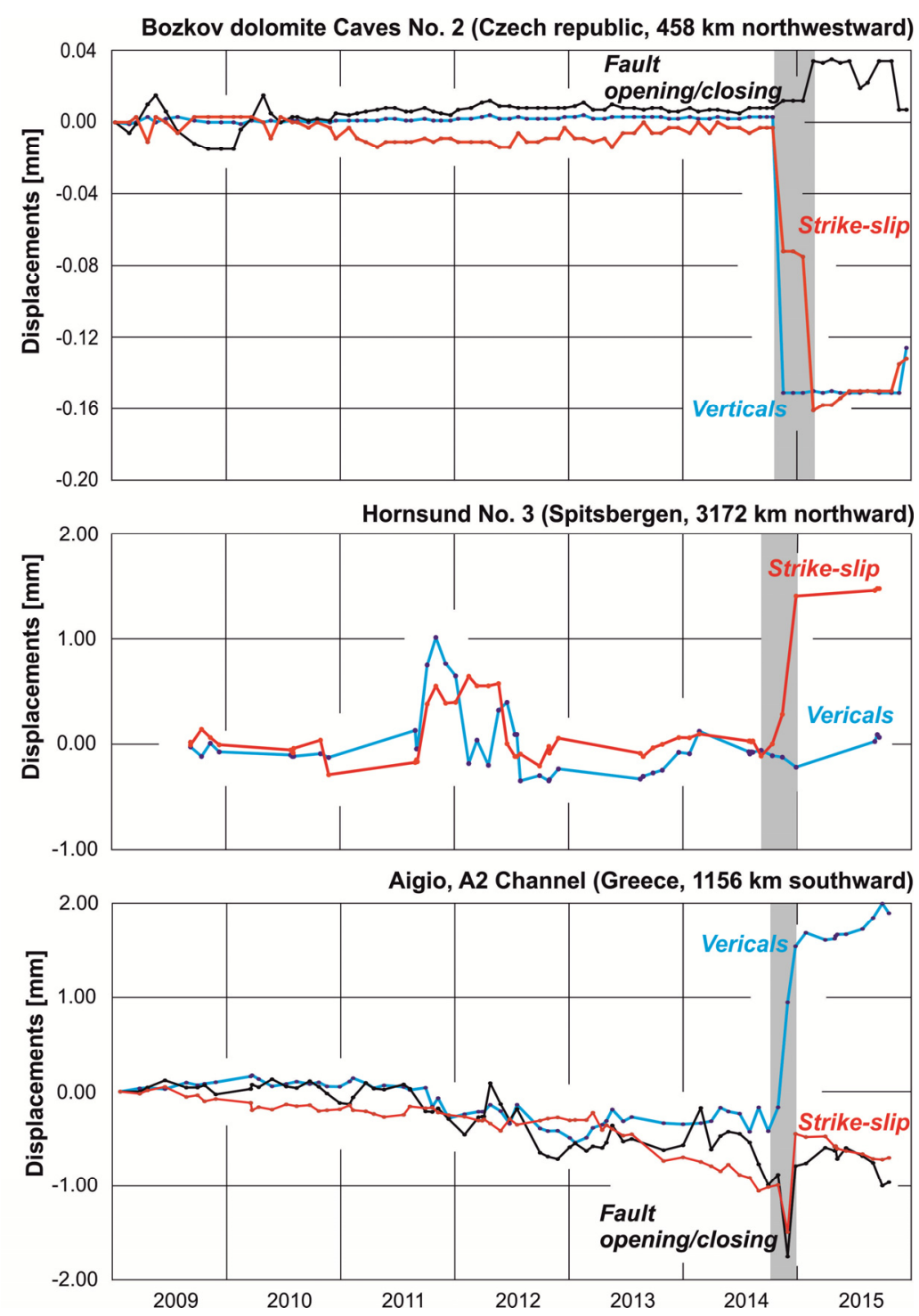

Fig. 11 Tectonic pulse (grey rectangle) that affected many fault displacement records with a plate-wide effect in the second half of 2014. The headings of the graphs show the distances from the Skalistý potok Cave. It is evident that the pulse affected the whole of the European plate and was simultaneously registered at the Skalistý potok and Drienovská jaskyňa caves. The sites belong to EU-TecNet (www.tectnet.cz). 